\title{
INTEGRATED LAND-USE MODELS FOR SPATIAL PLANNING SUPPORT: COUNTRY-SPECIFIC SOLUTIONS
}

\section{INTEGRÁLT TERVEZÉS-TÁMOGATÓ TERÜLET-FELHASZNÁLÁSI MODELLEK: ORSZÁG-SPECIFIKUS MEGOLDÁSOK}

\author{
Vilja VASZÓCSIK ${ }^{\mathrm{a}}$, Erzsébet VAJDOVICH-VISY ${ }^{\mathrm{b}}$ \\ ${ }^{a}$ Lechner Nonprofit Ltd., vilja.vaszocsik@lechnerkozpont.hu \\ ${ }^{\mathrm{b}}$ Budapesti Müszaki és Gazdaságtudományi Egyetem, vajdovisy@gmail.com
}

Cite this article: Vaszóczik, V., Vajdovich-Visy, E. (2017). Integrated land-use models for spatial planning support: country-specific solutions. Deturope, 9(3): 12-28.

\begin{abstract}
A mai világban a tervezés szükülő erőforrások közepette kénytelen müködni és választ keresni a kor kihívásaira. A fejlett térségekben és különösen a nagyvárosok környékén intenzív a területért folyó verseny, mert a szuburbanizáció gyors ütemben alakítja át a település hálózatot és a terület felhasználást . A területi tervezés ilyenkor, a területi tervezésért folyó küzdelem során a mediátor hálátlan szerepét tölti be, irányítani próbálja a fejlesztés folyamatát és közben igyekszik védeni a szabad területeket az egészséges életfeltételek és a természeti értékek megóvása érdekében. A kétezres években az integrált döntéseket segítő rendszerek (DSS) egyre népszerübbek lettek a területi tervezők és döntéshozók körében. Segítenek abban, hogy a döntési folyamatokban a tudományos ismeretek jobban érvényesüljenek. A legutóbbi években a Lechner Tudásközpont munkatársai a magyarországi feltételekhez adaptált döntés segítő módszert fejlesztettek ki, az u.n. Magyar Területi Döntés-segítő Modellt. A jelen tanulmány ezt a modellt mutatja be és azt, hogy a modell hogyan hasznosítható a területi tervezésben és a döntéshozásban.
\end{abstract}

Kulcsszavak: területi tervezés, döntés-támogató rendszer, területfelhasználás modellezése, regionális tervezés, városi beépített területek terjeszkedése

\begin{abstract}
The key issue of contemporary planning is that it has to work within and respond to the scarcity of resources. The competition for land is particularly intense in growth areas, especially around cities, where suburbanisation is accelerating and causes fundamental change of the evolved settlement pattern and the structure of land use. Planning in this situation must perform the difficult role of mediator in the competition for land, guiding the growth process and at the same time saving and protecting the open spaces which are indispensable for healthy living and are significant natural heritage. The integrated decision support systems (DSS) are more and more popular among spatial planners and decision makers since 2000. These systems facilitate to incorporate scientific knowledge in the decision making process. During the last years in the unit for spatial planning of the Lechner Knowledge Centre we developed for a country specific spatial decision support, the Hungary Spatial Decision Support model. This study introduces this model and how it can assist territorial planning and decision making.
\end{abstract}

Keywords: spatial planning, decision supporting system, land use modelling, regional planning, urban expansion 


\section{INTRODUCTION}

The purpose of this paper is to present a model estimating the changing process of land use in response to the change of other factors occurring in the city structure over time, and to demonstrate its uses in spatial and city planning.

The key issue of contemporary planning is that it has to work within and respond to the scarcity of resources. In this strained situation the special concern of spatial planners is the limited availability of land, which is an object of competition of various development needs and aspirations, while it is also natural resource to be protected. The competition for land is particularly intense in growth areas, especially around cities, where suburbanisation is accelerating and causes fundamental change of the evolved settlement pattern and the structure of land use. Urban sprawl is a contemporary process, when urban growth goes beyond the city boundaries without or with little or ineffective control.

Planning in this situation must perform the difficult role of mediator in the competition for land, guiding the growth process and at the same time saving and protecting the open spaces which are indispensable for healthy living and are significant natural heritage.

Urban sprawl is an increasing world-wide challenge, it can be well observed in Hungary too. The process involves a variety of environmental and social problems; one of these is the issue of the long term maintenance of resources. Urban sprawl is a threat for the condition of the arable land, water resources, and special habitats and for the protection of floodplains. The uncontrolled urban sprawl and the involved problems are especially serious in areas where the regulatory power of spatial planning is inadequate. (Vajdovich-Visy 2006)

In Hungary spatial planning at regional and local levels take efforts to mitigate urban sprawl. The plans, however, with all the concern to take an integrated approach and long-term view, are often inefficient to respond to the on-going processes and maintain a long-term perspective at the same time. Therefore the greatest challenge for the planners is to predict, analyse, evaluate and demonstrate before the public and the decision makers the consequences of the evolved trends and the various, inter-related impacts of the development plans and planning regulations. An important aid in this effort is the application of spatial decision support systems (DSS). The software that allows for the development of DSS is capable of the complex management of the various inputs - data, development priorities and regulative measures - and through a series of simulations assesses their social, economic and environmental impacts and makes future visible on the map. Integrated approach from the beginning of the planning process facilitates to develop alternative proposals and then to 
identify a decision which is acceptable for the majority of the agents (Mrs. Jaschitz 2012). The article will present the Hungarian Spatial Decision Support System developed in the spatial planning unit of the Lechner Knowledge Centre and its potential application.

\section{Planning system in Hungary}

Planning has traditionally been a complex, inter-related exercise, an effort to facilitate the delivery of some desirable - economically productive or visually magnificent - state or else the improvement of the devolved physical and social conditions. By now, in a pluralistic and complex society which is exposed to a multitude of external effects, planning has tremendously grown in complexity while compelled to face and deal with many inter connected and contradictory challenges. It is therefore necessary and advisable for planning to seek the support of conventional as well as contemporary approaches and techniques proposed for instance by information technology.

As a matter of fact, the use information technology is indispensable in this world the immense data sets to be managed.

In Hungary there has been a rationally thought out, double faced spatial planning system arranged in a hierarchical set adapted to the country's administrative structure. The vertical layers consist of the national level, the regional level (of the 19 counties and the capital city) and the local level of the urban municipalities (cities and towns) and district level if the municipality is subdivided into districts. At times the need emerges to prepare a spatial plan for an area the borders of which cut across administrative boundaries, in such a case a so called special plans are prepared. The approval of the plans corresponds to the administrative level, that is, the national government or the national assembly, the county authority or the county assembly and the local authority etc. are responsible for approval. The double face follows from the fact that socio-economic and physical plans are distinguished. Both are arranged in the same hierarchical system. This system is determined and enforced by law. The lower level and more detailed plans must be in line with and specify the directions outlined in the upper levels.

This clear cut, logical and rigid planning structure is suitable for centralized, monolithic systems; though even in such cases unexpected changes, unforeseen trends may occur, which undermine the smooth operation of the rational, top-down planning process.

At an early stage of the use of information technology the rational comprehensive mathematical models, which this technology offered suited to the evolved hierarchical planning system. The approach offered a logical and deliberative framework identifying and 
quantifying problems, objectives, predicting and projecting outcomes, testing plans of action and considering a range of alternatives and ensureding that the best plan of action is chosen. In this way it helped the consolidation of authority and power. It placed power and trust in the hands of the planner and decision maker who is seen as an expert bearing all the information required to solve problems.

The use of rational comprehensive mathematical models was a contemporary, sophisticated disguise of the fundamentally conservative planning system.

During the recent decades the complexities, uncertainties, the interplay of economic and social processes have come more and more into the limelight of concerns. Furthermore, the spatial processes underwent fundamental transformations in Hungary just as all over the world. The linear trends gave way to multiple dependencies and interrelations. The transition to market economy and political democracy were only the forerunners of change followed by changing demographic trends, the globalisation of the economy, culture and mobility, environmental threats and multiple dependencies on transnational influences and domestic expectations.

Planning accustomed to setting magnificent long-term visions objectives and managing growth and development while struggling with the scarcities of the present day, including the scarcity of reliable data, is now made responsible for the failure of the forecasts and is compelled to face unexpected challenges, manage uncertainties while maintaining a cautiously positive if not optimistic attitude. Data and expert forecasts of all kinds are available in abundance, but they are many times mutually contradicting and therefore very difficult to find the right way and make the right assumptions. Without the expertise of information technology it would be impossible to cope with the profusion of numbers, ratios, and interdependencies.

Within the new context the overall, statutory framework of planning remained. Nevertheless, there have been fundamental changes in attitudes, interrelations and approaches. The rigidity of the hierarchical order gave gradually way to flexibility and interactions.

Plan making has traditionally been a multi-disciplinary and multi-actor procedure. In the process of plan making several experts were involved, like architects, transport engineers, cartographers, and later economists and environmental experts. The various disciplinary tasks were distributed among the experts, each worked out the chapter on his/her theme like the transport system, the parks and urban open spaces, housing, manufacturing etc. and usually the architect planner was responsible to summarize and work out the land use plan as well as the zoning plan and building regulations. The procedure was similar in the preparation of the 
development plan; in this case either an architect planner or an economist was responsible for the summary. The participants of the procedure were obliged to consider the work of their colleagues, adhere to the decisions contained in the plans of the upper levels and take account of the plans of the same level (for instance the plans of the neighbouring municipality) and the lower levels. Responsible planner was the title of the head of the team in both cases. Finally, the plans of both kinds were submitted to the commissioning (local, regional or national). The procedure ended with a formal meeting. Active cooperation authority was not required, though it took place on a voluntary basis due to the intellectual preferences of the participants.

The need for active cooperation of all actors emerged and increased when the actual role of planning - instead of producing sets of official documents - was more and more recognized as a tool of guiding development and change and as a response to known and newly arising challenges. The planners wanted to discuss their concerns with the others, they were interested to see how a problem or a potential appears from the point of view of another discipline or at another spatial level. The number as well as the quality of formal informal discussions has been growing, just as those of local, national and transnational conferences. The professional associations like the Hungarian Society for Urban Planning played an important part in this change of awareness. The cooperative approach is now a natural, integral feature of planning in this country too.

Another process, which had fundamental impact on planning, began in the 1980's already. It was the beginning of the "city protection movement" concerned with the saving of the local environmental assets. As a matter of fact, in Hungary this was the first voluntary, social initiative. It was born in Budapest and rapidly extended to the other local communities, both urban and rural. In this movement the citizens found the way to express their views, preferences and concerns with the conditions of the place where they lived. The city protection movements were the incubators of public participation. Gradually the movement as well as the social climate thus created made it unavoidable to listen to the local public view on the needed and planned changes in the local environments. Saving the local heritage as well as the landscape assets and protesting against arbitrary decisions, preventing undesirable changes are on the banners of this movement. Public consultation of plan proposals and the need for listening to the people's views were largely promoted by this movement.

The planners today are no longer critical bystanders viewing the sphere of reality from their elevated professional position, but are part of the world full of contradictions and concerns. They need the support of tools offered by information technology rather than overall comprehensive models. 


\section{Spatial decision support systems}

The integrated decision support systems (DSS) are more and more popular among spatial planners and decision makers since 2000. These systems facilitate to incorporate scientific knowledge in the decision making process (H. Van Delden 2011). For the decision support system, to be capable of supporting the decision making process it is indispensable to adapt to the available methods and procedures rather than displacing the current practice (McIntosh et al 2007).

For supporting the spatial decision these integrated systems must be capable of modelling the complex interactions between the social and environmental processes. During the last ten years the focus has been on the complex linkage of models of different disciplines, and the improvement of software capacities enabled to build decision support systems incorporating integrated models (H. van Delden 2011).

The different spatial decision support systems or named as integrated modelling systems for spatial planning support have a number of common characteristics (H. van Delden 2011). The system is:

- able to support policy relevant questions,

- pays particular attention to long-term problems and strategic issues,

- aims to explicitly facilitate group interaction and discussion,

- applicable to complex and ill-structured decision domains, characterized through a large number of actors, factors and relations, a high level of uncertainty and conflicting interests of the actors involved,

- is user friendly in entering input, viewing output and analysing results,

- harmonizes actual data and process knowledge from different disciplines,

- can operate on different scales and resolutions when required,

- may be fully dynamic with feedback loops between individual models,

- is built as a flexible component-based system that can be extended with additional modules over time.

During the last years in the unit for spatial planning of the Lechner Knowledge Centre we developed for a country specific spatial decision support, the Hungary Spatial Decision Support model with the above mentioned characteristics. It has been developed using the Geonamica software platform with the help of RIKS (Research Institute for Knowledge System). 
This decision support system contains two model components:

- The spatial interaction component, a so called regional model simulates the impact of the attraction of the various regions upon the inhabitants and the industry. The model distributes the quantity of national growth (of inhabitants and workplaces) based on the attractiveness of the regions (administrative counties) according to migration characteristics, initial status and their relative position (RIKS 2011)

- The land-use change component, which is a cellular automaton model. This model simulates the competition of the different actors for the available space. This competition forms the spatial structure. The main factors of the model of land-use change are the physical capabilities of the land-use categories, the accessibility and the interaction of the categories over time and space. These factors determine the potential of the land-use categories for change, and upon this the land use can be calculated on cell level (RIKS 2011).

The two components of the decision support system are connected in such a way that the data on population and jobs calculated by the regional model are linked to one or if possible to several land-use categories. Thereby the social economic data represent the territorial need as inputs in the land-use model, where the probable future land-uses, their spatial allocation, that is, the future spatial structure are calculated according to actual needs.

The modelling of the land-use change helps to reveal and analyse the causes and consequences of the process of change, therefore it helps to better understand the system and behaviour of the land use system and so it supports spatial planning (Peter H. Verburg et al 2004).

\section{OBJECTIVES AND METHODS}

\section{Development and application of the Hungary Spatial Decision Support System}

The application of the decision support model on a concrete planning area and the solution of actual spatial problems begin in all cases with calibration. The relevant land use categories are identified and the previous land use change processes are explored and by means of calibration the characteristic processes which are likely to influence the future land use pattern can be revealed. (Fig.1) (Vaszócsik et al 2004) 
Figure 1 Scheme of the operation of the decision support system

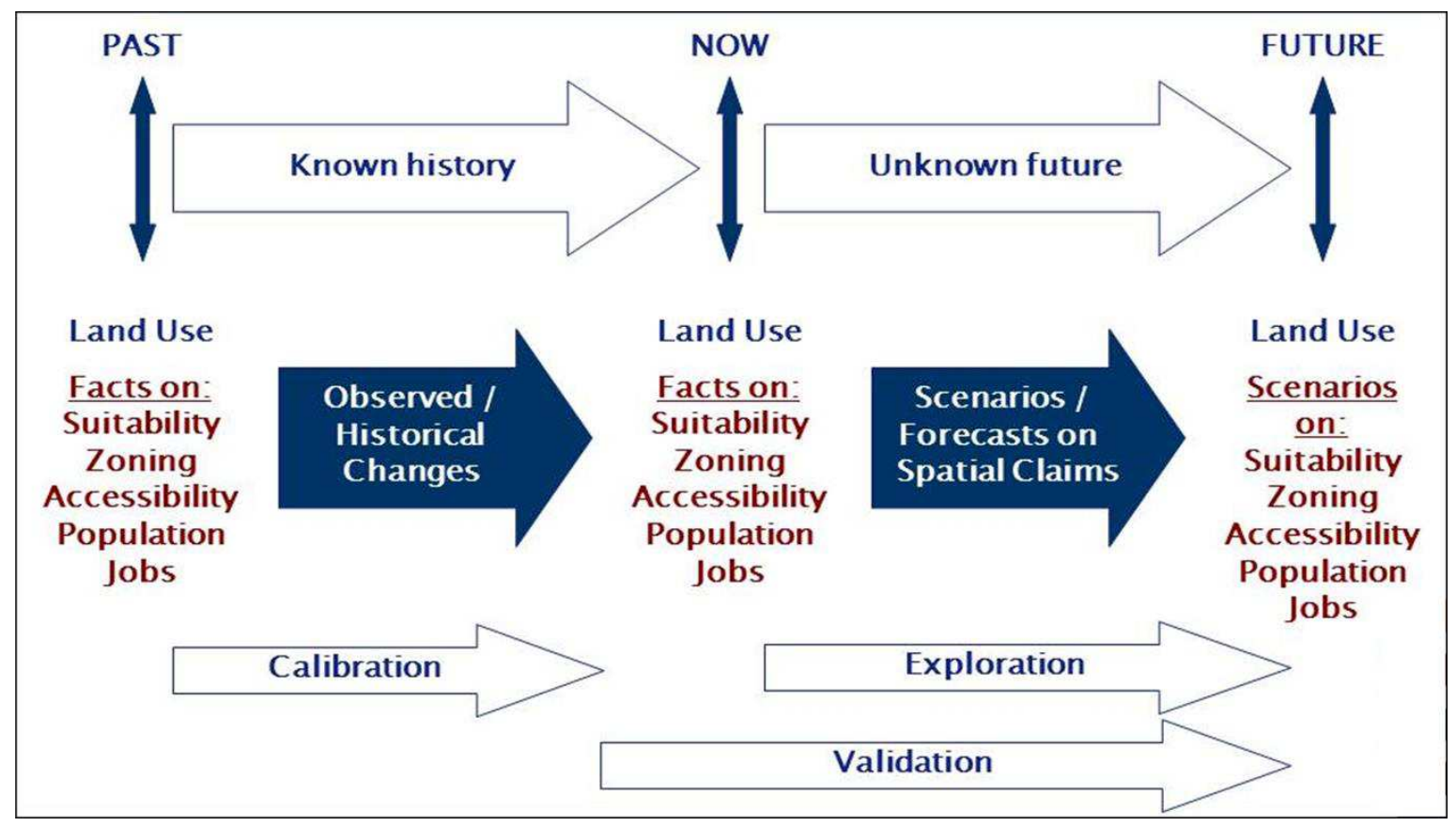

Source: RIKS 2011

At the beginning of the development of Hungary Spatial Decision Support System the land uses pertaining to the three sub-systems were identified. The space for the operation of the social sub-system is provided by the settlements (cities and rural communities). A significant part of the economic sub-system is also located in the settlements, within the built-up areas, where the extensive areas needed for the operation of the manufacturing and service sectors can be delimited and identified as manufacturing and commercial areas. Agriculture is the section within the economic sub-system that has the greatest area need consisting of different cultivation areas, like arable land, orchards, vineyards. The extensive forest areas belong partly to the economic subsystem, but in their natural condition they belong to the ecological sub-system. Other important constituent parts of the ecological sub-system are the land uses such as natural habitats, which can be identified as woodland, natural grassland, wetland, water surface. Information on these land uses is available in the land cover data bases. For the whole territory of Hungary the data base of the Corine Land Cover is available for a series of time periods. The Corine Land cover contains and offers quantified, comparable data for the whole European territory at 1:100,000 scale. The size of the smallest interpreted object is 25 hectares, the minimum width is $100 \mathrm{~m}$ (Mari I. 2010).

By means of the available data we identified the relevant land uses for the decision support system, and produced for the initial country map with $250 \mathrm{~m}$ x $250 \mathrm{~m}$ grids. 
For modelling the land-use changes we compared the overtime changes of the data at our disposal and identified the national level process of the land-use changes. For the model building, for calibration we mapped these processes.

- Through calibration we revealed the inertia of certain land-uses, the direction of their transformation, regularities and their mutual attraction or repulsion. The time and spatial interaction of the different land-uses is known as neighbourhood impact, which is applied by several land-use change models as neighbourhood rule (Hagoort, Geertman and Ottens, 2008). Consequently, in our Hungarian model we also determined the neighbourhood rules relating to different land uses.

- For identifying the land-use potential exposition, soil characteristics, height and habitat features can be considered. In the course of tuning we set a separate rule for each factor which, by means of the adequate combination method leads to the formulation of the map of the land-use potential of a given use, that is, the optimal location in terms of natural endowments.

- Accessibility represents the impact of infrastructure networks on land-uses. The impact of road- and railroad network on the location of the new built up areas was modelled first of all.

- In the last phase of calibration the content and impact of regional and local (development and physical) planning regulations as well as other regulations and their long-term influence on land uses were built in the model. The hierarchy of the different zoning regulations determines the combined zoning regulation.

\section{Modelling of spatial interactions}

- For the spatial allocation of population and economic activities the model analyses a so called standard potential: each region is in competition with all the others for new residential areas and for the attraction of economic activities on the basis of their relative geographical position, activity rate, size of population, number and type of existing activities, relative access to public and private transport systems (RIKS, 2011).

- For calibration we analysed first of all the distribution of the number of population/workplaces among the regions (administrative counties) and explored the migration trends. By means of the historic range of data we calibrated the 
attractiveness of the area units, spatial stability of population/workplaces and the main inter-regional migration flows.

- As a final step of calibration we supervised - by means of running for a long-term period - the operation of the model: we analysed whether the distribution of population and workplaces, as set in the model, was realistic enough, we explored the causes of eventual extremities and refined the setting, where it was necessary.

Finally, we linked both components of the decision support system and specified the area need corresponding to the number of population/workplaces. The regional activities can thus be interpreted as spatial requirements, that is, for the location of an activity in a certain region specific conditions are to be met. The model of land-use change allocates the spatial requirements in compliance with the attractiveness of the cells, which depends on the availability of good quality land, position of the area in the zoning system and relative accessibility to waters, roads, public transport network.

As a result of calibration a so-called initial scenario was worked out, which models the future land-use system in accordance with the evolved trends.

Figure 2 Developing scenarios for the land-use model

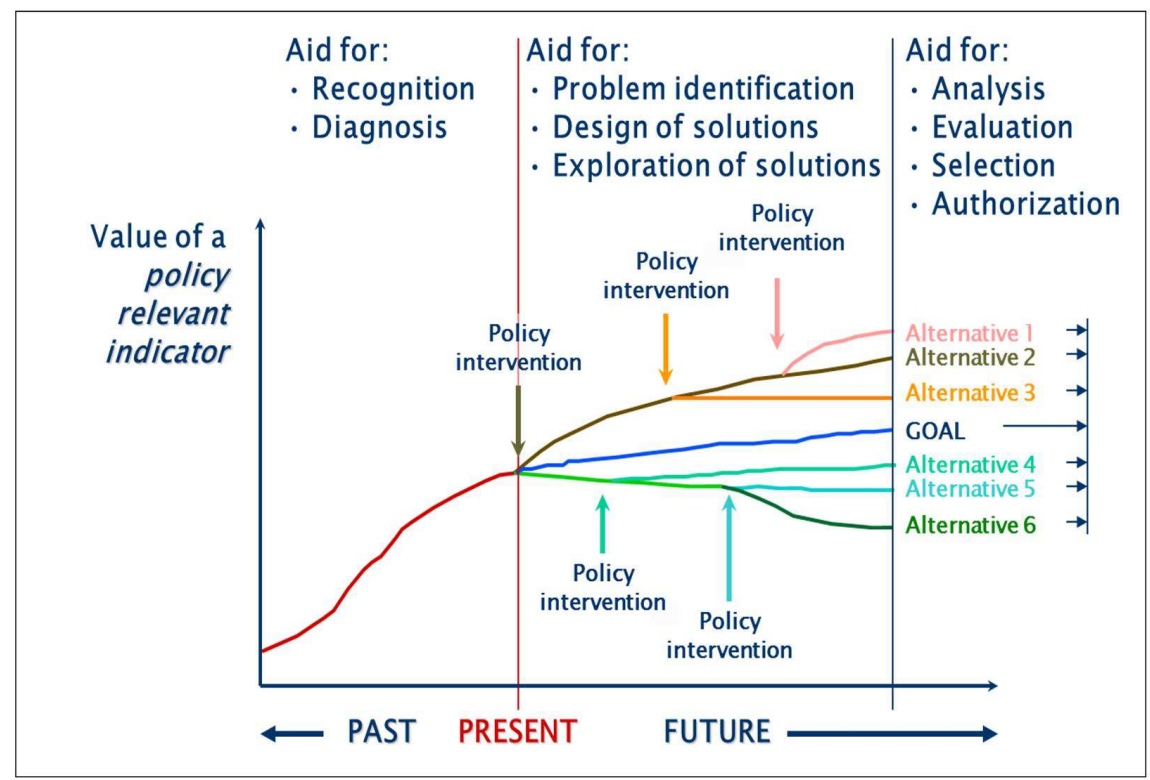

source: RIKS 2011

For the support of decision making, in the course of modelling further, alternative scenarios can be developed at definite decision making points and the possible directions of 
the process (Figure 2). The output maps modelled following the scenarios facilitate the selection of the course of action which best leads to the stated objectives.

The alternative scenarios depend on the policy actions and regulations and the probable processes, which can be built into the system. These may be the following:

- Change of the socio-economic environment: predictions of population and employment change, quantified development targets (e.g. selection of development poles ${ }^{1}$, population forecast (Földházi 2015).

- Change of land use requirements: future change of the extension of a land-use category (e.g. afforestation strategy ${ }^{2}$, reform for greening agriculture ${ }^{3}$ )

- Development of the infrastructure network: alternative routing of the planned lines, time-phasing of implementation.

- Change of zoning regulations: incentives for certain land-uses, enforcement of restrictions or mitigation of restrictions (e.g. new zoning regulations).

The alternative scenarios and the corresponding modelled output maps are essential tools of consultation with developers, decision makers as well as all stakeholders. The output maps and the visualized process of land use changes following from alternative decisions are convincing tools for attaining consensus and selecting the most appropriate scenario.

\section{RESULTS}

For demonstrating and testing the role of spatial planning and the application of the spatial decision support model in safeguarding those areas which may be important in adaptation to climate change we have selected the case of chief town of Györ-Moson-Sopron county (Györ) and its urban region (Agglomeration of Györ). We also modelled the impact of the introduction of new zoning regulations. Györ Agglomeration is in the north-western part of Hungary, covering an area $1607 \mathrm{~km} .2$ The city and the surrounding belt have a total of 257 thousand inhabitants. In Hungarian relation Györ is a dynamically developing industrial centre with fast growing residential and industrial areas. Between 2000 and 2012 - according to the Corine Land Cover database - industrial areas increased by 30\%, the urban area expanded by $4 \%$. According to the estimation and the results of our modelling of the future land development this growth will continue in the coming decades. However, Györ is situated at the confluence of rivers and surrounded by a flood prone area. The river banks are important habitats, parts of the National Ecological Network as ecological corridors. 
Substantial part of the arable land has very high quality in terms of plant production and has excellent water management properties. The above mentioned areas play very important role in climate change adaptation; therefore it is essential to protect them from urban sprawl. In this area the impact assessment of spatial plans on land use are particularly important. It is fundamental that spatial plans should have an influence on the control of area growth. We formulated some recommendations regarding the possible land management roles of spatial plans as well.

By means of land use change modelling we analysed the probable directions of the growth of built up areas in the Györ urban region. The comparison of the outcomes of three scenarios highlighted the future conflicts and the impact of the proposed regulations.

First we analysed the impacts of current regulation. In the case of the "no regulation" scenario the simulation of future land-uses pointed out conflicts in several parts of the urban area. The high quality arable land suffered the most extensive damage due to the growth of built up areas. (Fig. 3 and 4 )

Figure 3 Conflict areas in the high quality arable land

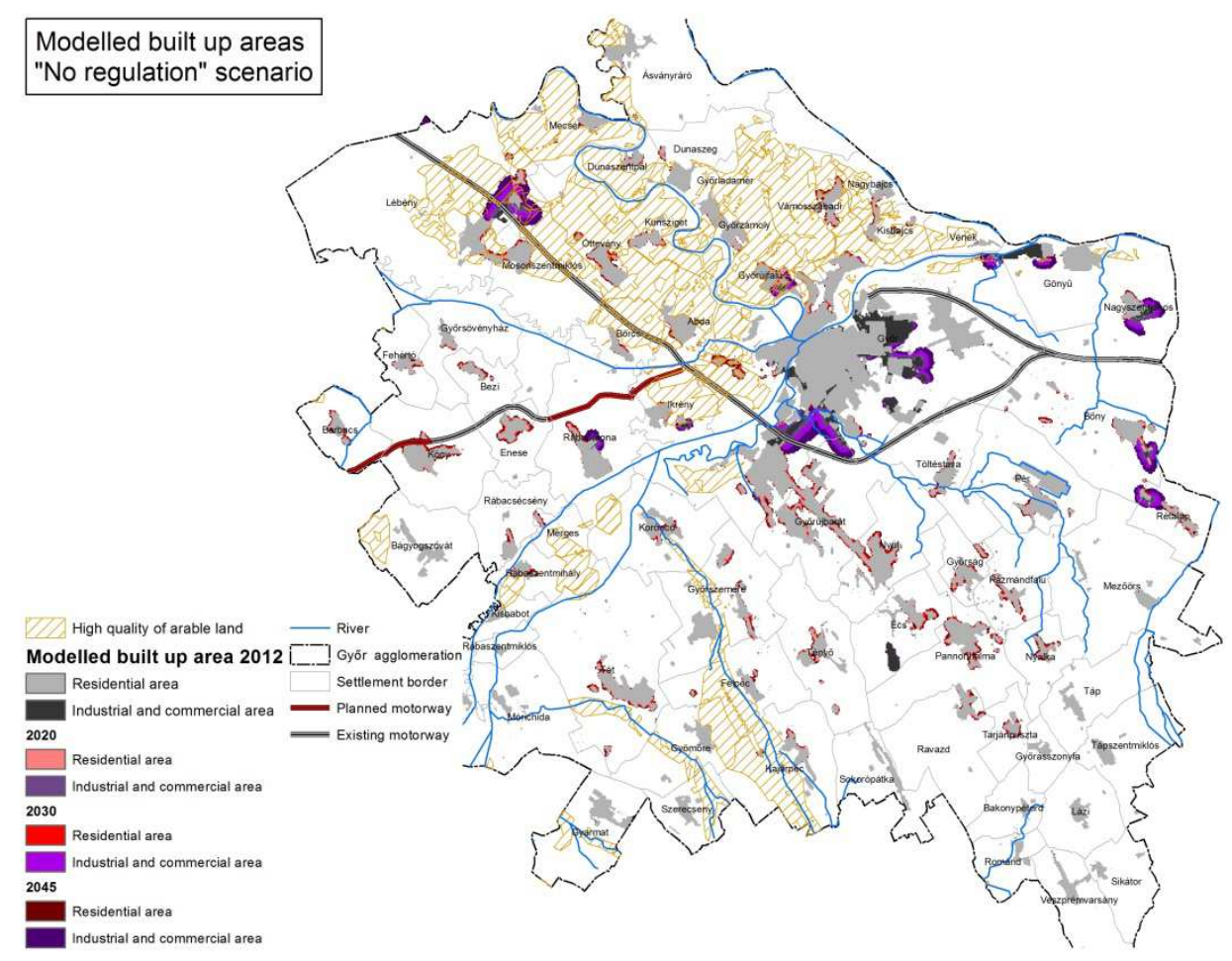

Source: own editing using the TEIR database 
Figure 4 Conflict areas in the high quality arable land

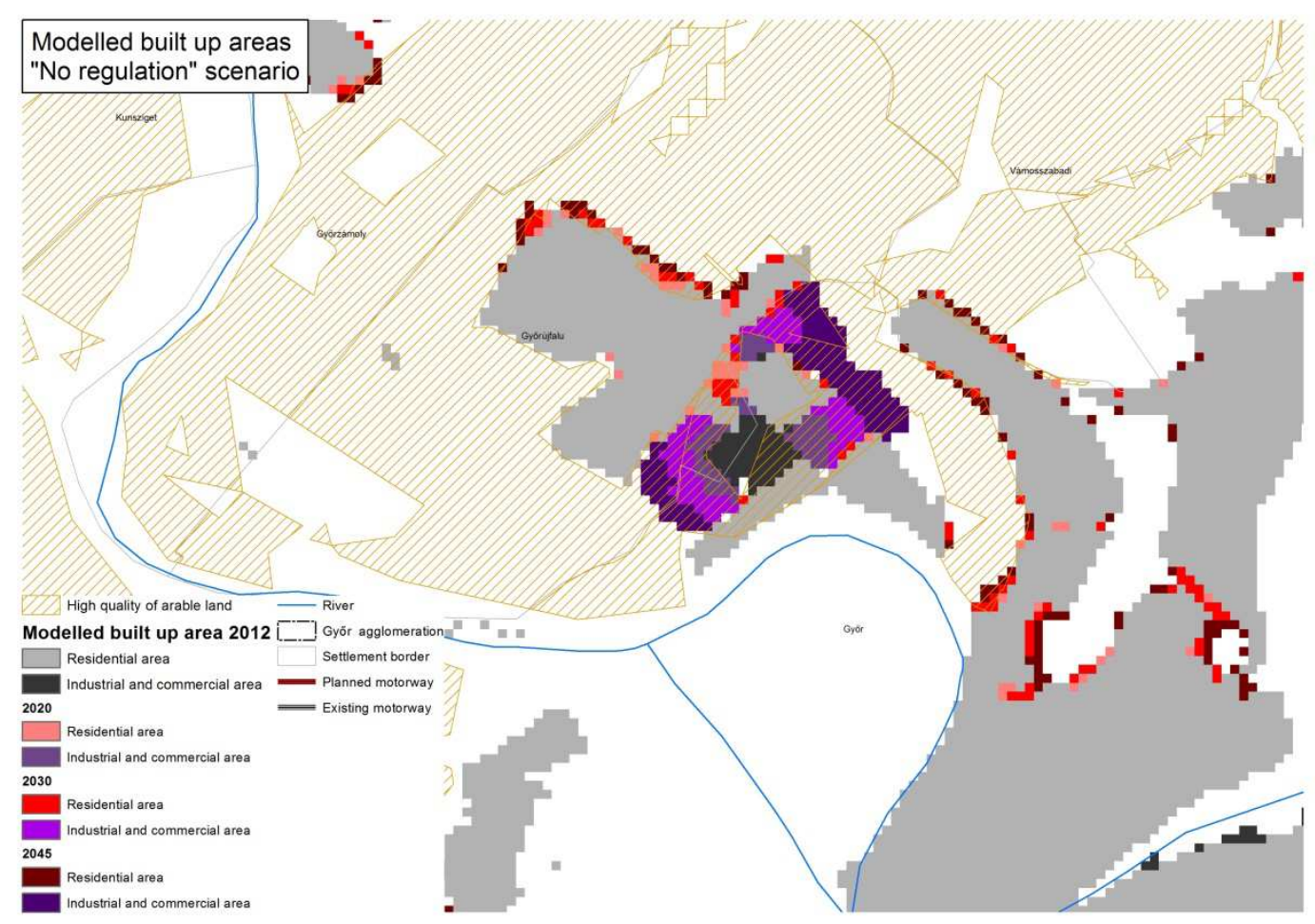

Source: own editing using the TEIR database

The growth of built up areas would also affect some minor parts of the ecological network in the case of no regulation.

We wanted to find out whether these areas, which are essential for adaptation to climate change, are protected enough with regulations, to attain that the growth of built up areas can be limited or avoided. Another question is about the alternative locations for building development. Therefore a scenario was worked out assuming regulations for the limitation of built up area growth.

In a conflict area next to the city the modelling of building development indicated the growth of built up area in spite of the current regulation, though at a lesser rate than in the case of no regulation.

At another place a little further away from the central city building development was averted by the force of regulation, and therefore the ecological network avoided the risk (Fig. $5)$. 
Figure 5 Long term land use pattern under the current regulation in the ecological network

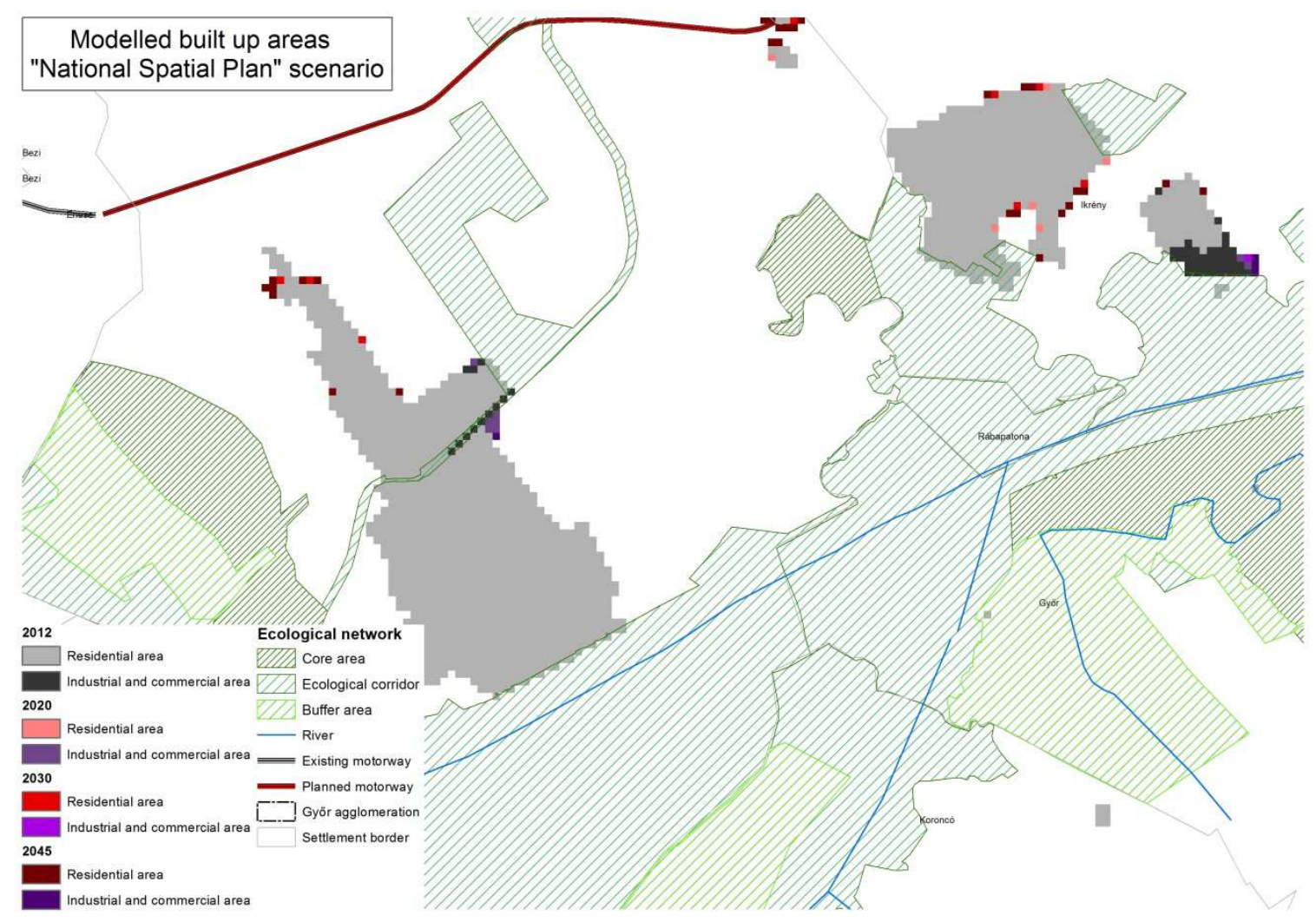

Source: own editing using the TEIR database

The comparison of building development in both scenarios indicates that in case of regulation in force the growth of built up areas will continue though at a limited rate in the urban region of the city of Győr (Fig. 6).

Figure 6 Comparison of the consequences of no regulation and current regulation
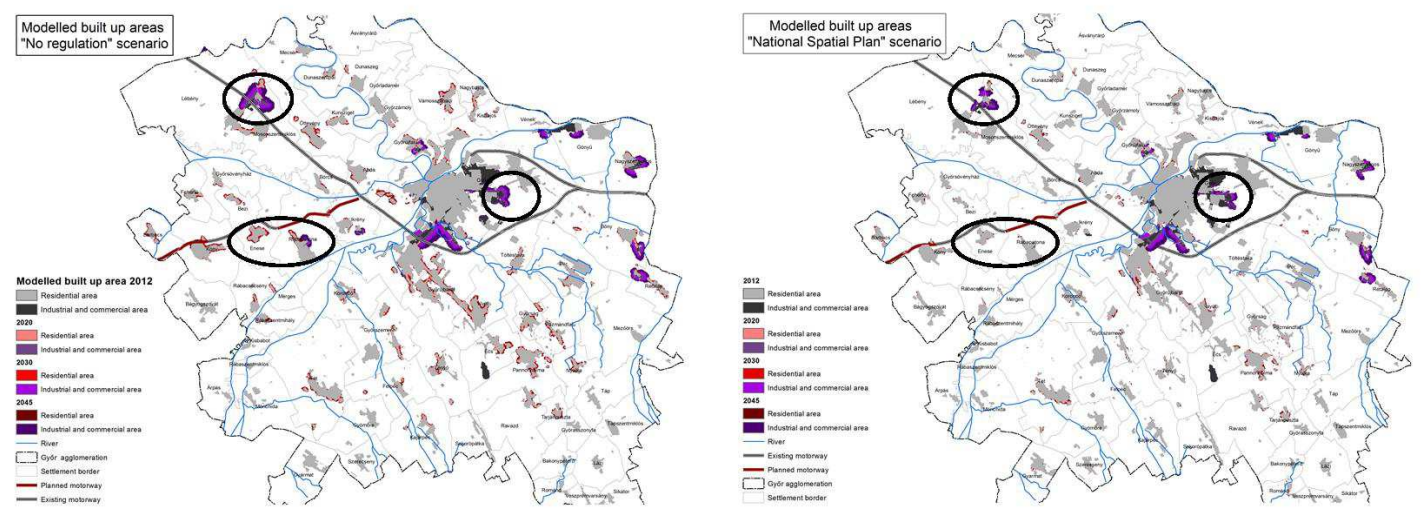

Source: own editing using the TEIR database 
In the elaboration of the third scenario we assumed that climate change would involve more robust floods than so far, and then the currently flood-proof, deep lying areas will be more vulnerable, because the dams would not be able to channel the more abundant flow of water. We also relied on the domestic results of flood risk mapping. In this scenario we assume the launch in the endangered areas further regulative measures of flood risk management, which restrict the development of new built up areas. Under the impact of the proposed measures the location of new industrial areas forecast for 2045 significantly differs from the one evolving in case of the continuation of current regulations (figure 7).

Figure 7 Impact of the new restricted regulation on long term land use structure

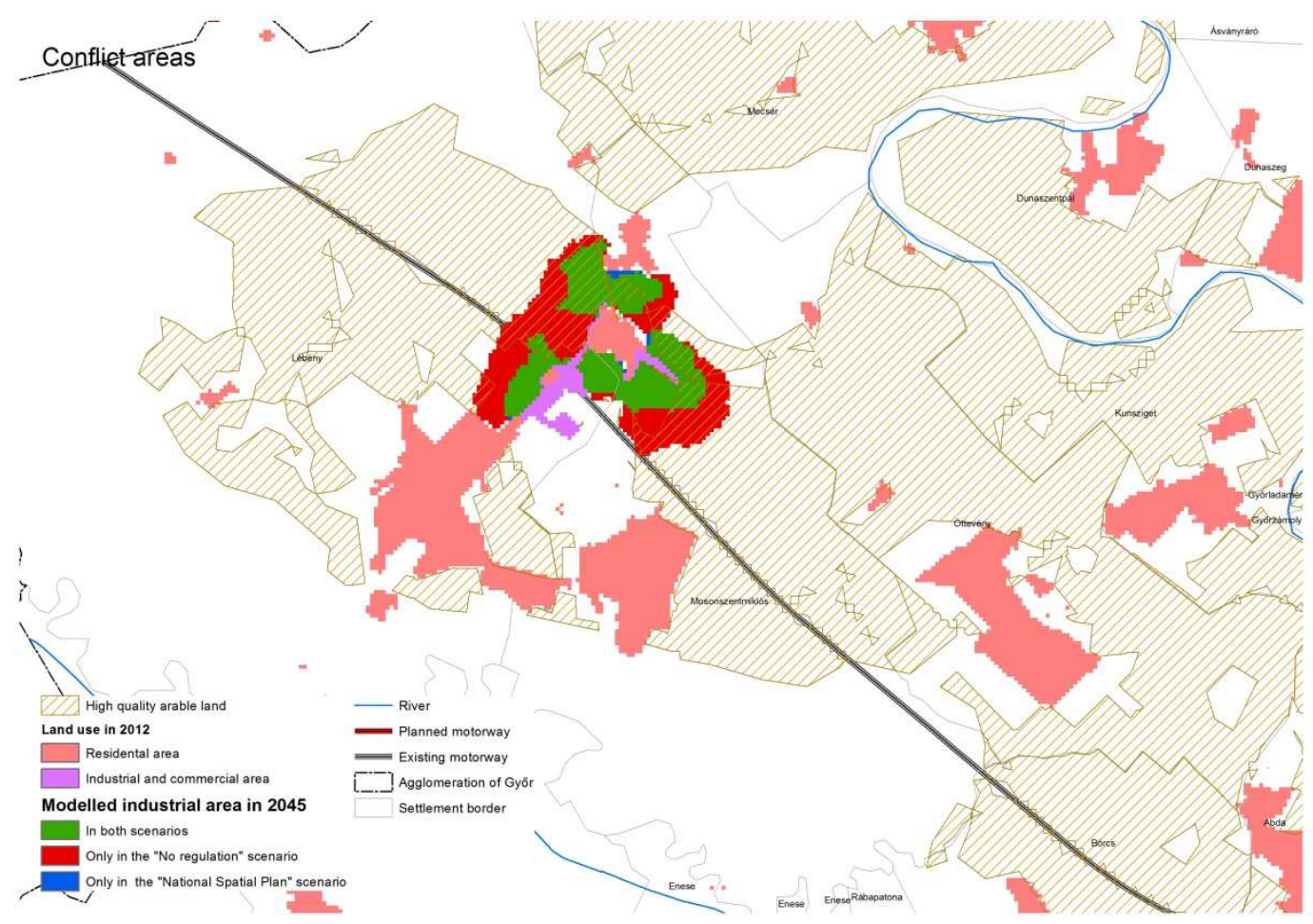

Source: own editing using the TEIR database

The comparison of the location of new industrial areas in both scenarios demonstrates that the further land use regulation measures of flood risk management restrict the development of new industrial areas in the direct vicinity of the city of Györ (purple colour), but there is ample potential for new investment somewhat farther from the river (turquoise colour).

\section{DISCUSSION}

The adaptation to climate change would require an approach to land use regulation which is appropriate for the character and role of specific areas. These areas are basically of three kind: 
- areas of green infrastructure which mitigate the adverse impacts and promote the migration of the species

- areas which gain added value under the impact of climate change (e.g. high quality arable land)

- the areas suffering natural risks (e.g. areas with increasing frequency and magnitude of flood risk)

A more sophisticated land use regulation (which involves the restriction of building development and the enhancement of ecological land cover) might involve consequences in the economic and social urban structures, which need further consideration. For the appropriate functioning of the specific areas additional interventions are needed (e.g. afforestation, wet land rehabilitation).

\section{CONCLUSION}

The proposed land use regulation does not only restrict, but also promotes particular land uses of some crucial areas:

- the suitable land cover of areas of potential green infrastructure - serving for mitigating the adverse impacts of uncontrolled water flow, habitat fragmentation and soil degradation - can be grassland or woodland;

- the high quality arable land, should be under special protection with the help strips of woodland

- the areas exposed to highly frequent and robust floods need water resilient land cover such as swamp forest, wetlands, and even temporary water surfaces

The proposed regulation and recommendations would contribute to a more natural land use structure and enhance the connectivity of habitats, reduce the runoff and the potential damages of climate change. In consequence,, the overall land use, including the urban structure would change. The area allocated for industrial and urban investments will be scattered, but the advanced industrial technologies and transport links will easily adapt to such new conditions.

The application of the Spatial Decision Support System and the model developed for the context in Hungary has proved to be a useful tool by forecasting the land-use change process in different regulatory frameworks. The visualisation of the alternative processes and consequences of change helped to come to appropriate conclusions and demonstrate the 
alternative futures before decision makers and all stakeholders in the course of planning consultations.

\section{REFERENCES}

Biesbroek, G.R., Swart, R. J., \& Van Der Knaap, W. G. M. (2009). The mitigation-adaptation dichotomy and the role of spatial planning. Habitat International, 33(3), 230-237

Council of Europe Conference of Ministers responsible for Spatial/Regional Planning (CEMAT) (2011). Basic texts 1970-2010 Territory and landscape, No. 3. Council of Europe Publishing

Földházi, E. (2015). A népesség szerkezete és jövője. In: Monostori Judit - Öri Péter - Spéder Zsolt (szerk.): Demográfiai portré 2015. KSH Népességtudományi Kutatóintézet, Budapest: 213-226.

Hagoort, M., Geertman, S., \& Ottens, H. (2008). Spatial externalities, neighborhood rules and CA land use modeling. Annals of Regional Science, 42, 39-56.,

Jaschitzné Cserni, T. (2012). TICAD SDSS - A tervezés új dimenziója, $\mathrm{http}: / /$ www.terport.hu/webfm_send/2805

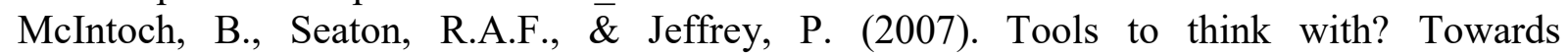 understanding the use of computer-based support tools in policy relevant research. Enviromental Modelling and Software, 22(5), 640-648.

Verburg, P. H., Schot, P. P., Dijst, M. J., \& Veldkamp, A. (2004). Land use change modelling: current practice and research priorities. GeoJournal, 61(4), 309-324.

RIKS (2011). Metronamica documentation, RIKS, Maastricht, The Netherlands

The Parlimentary Act XXVI of 2003 on the National Spatial Plan

Vajdovichné Visy, E. (2006). A területi tervezés alapfogalmainak értelmezése- A nemzetközi gyakorlat in: Váti Magyar Regionális Fejlesztési és Urbanisztikai Kht. Stratégiai Tervezési és Értékelési Igazgatósága: Egységes tervezési rendszer szakértői elökészítése. Budapest,

van Delden, H., Seppelt, R., White, R., \& Jakeman, A.J. (2011). A methodology for the design and development of integrated models for policy support. Environmental Modelling and Software,

van Delden, H., Seppelt, R., White, R., \& Jakeman, A. J. (2011) A methodology for the design and development of integrated models for policy support. in Enviromental Modelling \& Software 26(3), 266-279.

van Delden, H., Göncz, A., Hurkens, J., Nagy, Z., Tacheci, P., Vaneček, S., ...Vaszocsik, V. (2012). Integrating hydrology, land use and socioeconomics in supporting spatial planning for the Tisza basin. in Seppelt, R., Voinov, A.A., Lange, S. \& Bankamp, D. (Eds.) (2012). International Congress on Environmental Modelling and Software Society (iEMSs) 2012. Proceeedings from International Congress on Environmental Modelling and Software Managing Resources of a Limited Planet: Pathways and Visions under Uncertainty, Sixth Biennial Meeting, Leipzig, Germany pp. 2809-2816

Vaszócsik, V. (2016). Hazai tájhasználat változási folyamatok modellezése in: Horváth, G. (2016) (szerk.) Tájhasználat és tájvédelem - kihívások és lehetöségek Eötvös Loránd Tudományegyetem Földrajz- és Földtudományi Intézet Környezet-és Tájföldrajzi Tanszék Budapest.

White, R., \& Engelen, G. (1993). Cellular automata and fractal urban form: a cellular modelling approach to the evolution of urban land use patterns. Environment and Planning A, 25(8), 1175-1199. 